\title{
MONITORING MECHANISM FOR INVESTMENT DEVELOPMENT OF REGIONS' INFRASTRUCTURE
}

\author{
Halyna LESHUK ${ }^{1}$ \\ Hrushevsky Carpathian Institute, Interregional Academy of Personnel Management, Ukraine
}

\begin{abstract}
The subject of the research is the theoretical and methodological principles of the monitoring mechanism of investment development of regions' infrastructure. The objectives of the research are the generalization of theoretical and methodological bases of monitoring mechanism of investment development of regions' infrastructure, as well as analysis of the current trends of investment development of the infrastructure in the regions of Ukraine with the identification of positive and negative trends. Methodology. The article deals with theoretical and methodological approaches to the definition of conceptual foundations of the mechanism of monitoring the investment development of the regions' infrastructure with the help of general scientific methods of analysis: systematization and generalization, induction, and deduction. Results. It is proposed to interpret a monitor of the investment development of the regional infrastructure (IDRI) as a systematic and complex measurement of the indicators of regional infrastructure development, the number of implemented investment projects, monitoring compliance with the developed strategic regional programs and concepts, which will ultimately help to effectively and efficiently regulate the detected deviations and passing the appropriate decisions. The IDRI monitoring mechanism should also provide a possibility of creating a system for collecting and analysing data concerning the assessment of infrastructure objects by the territorial community, which will allow potential investors to focus not only on analytical data on monitoring of regional authorities but also to take into account the public interest in a particular region. The general principles of the monitoring mechanism of investment development of the regions infrastructure are proposed in the following directions: complex and system monitoring and data collection concerning the development of the regions' infrastructure, while the aggregate of indicators should reflect the change in the level of investment potential as a result of the implementation of measures and implementation of investment projects for the development of regions' infrastructure; assessing the level of effectiveness of regional infrastructure functioning, using comparative analysis procedures - the concept of benchmarking, which will allow reducing costs of improvement processes accordingly, as the best experience of management of other territories is studied and evaluated in order to use the acquired knowledge in the activities of the authorities. Conclusions. The researched theoretical and methodological principles of the monitoring mechanism of the investment development of the regions' infrastructure enable to substantiate the necessity of implementation of complex and system monitoring of the functioning of the infrastructure complex and the investment potential of regions. The researched tendencies of investment development of the Ukrainian regions'infrastructure allowed establishing significant spatial asymmetries, which negatively affects the implementation of both national development strategies and regional programs and concepts. Thus, the main directions of the monitoring mechanism of the investment development of the region's infrastructure in the composition should be based on analytical observation not only of the regional authorities but also potential investors and the territorial community. Practical meaning. On the basis of official static monitoring data of investment support and the level of development of the infrastructure complex of Ukrainian regions, trends of investment development of the regions infrastructure are investigated in the article, which allows noting about significant territorial imbalances as a level of investment support, as well as the efficiency of the functioning of the regions infrastructure complex, and this determines the need for the development of comprehensive regional development programs and proper control over their implementation in relation to investment regional infrastructure support. The system implementation of the mechanism for monitoring over the investment development of the regional infrastructure will facilitate the adoption of effective management decisions for all participants in the process, namely, the territorial community, investors, and regional authorities, which will increase the investment attractiveness of regions and the development of the Ukrainian regions' infrastructure.
\end{abstract}

Key words: monitoring, infrastructure, investment development, mechanism, region.

JEL Classification: R10, R58, E22

Corresponding author:

${ }^{1}$ Department of Economy and Enterprise, Hrushevsky Carpathian Institute, Interregional Academy of Personnel Management.

E-mail: galynaleshuk@gmail.com 


\section{Introduction}

In order to ensure efficient management of the monitoring mechanism for the investment development of the region's infrastructure (IDRI) and the ability to monitorand correct the deviationsin theimplementation of regional programs and the planning of infrastructure projects in a timely manner, an effective feedback system should be developed through the implementation of monitoring and evaluation. Monitoring is a constant process of gathering data about the process and indicators of the measures implementation, which may be achieved during the implementation of the management mechanism, implementation of infrastructure development programs adopted within this mechanism, implementation of infrastructure projects. Data received during the monitoring process can be the basis for assessing the investing effectiveness in infrastructure objects of the regions within the mechanism.

Generally, two main types of monitoring are defined (Lohutova, 2006):

1. Situation monitoring allows you to establish and fix the situation in the investigated phenomenon or process. It also involves collecting information about general trends in infrastructure development, changes in state infrastructure policy, institutional changes, etc.

2. Process monitoring represents the process of supervision over the implementation of the program (in whole or in part) and obtaining certain results for the short or long term.

In the scientific literature, monitoring is a process of tracking or measuring what is happening in the infrastructure sector of a region, it is a combination of internal monitoring designed to check the degree of progress in selected strategic areas to the main goal of the management mechanism and the achievement of individual goals, and external monitoring that involves the collection of information for a wider context, such as: changes in the state legislation, state policy, the situation in industries and neighbouring regions that have a strategic significance for the infrastructure for this region, the trends and dynamics of the region's social and economic development, institutional changes, etc., and ensures the implementation of the mechanism for managing the competitiveness of a region through the development of its infrastructure in accordance with the interests and capabilities of the stakeholders in the region (Lohutova, 2006; Manylich, 2005).

Thus, it is proposed to interpret a monitor of the investment development of the region's infrastructure (IDRI) as a systematic and complex measurement of the indicators of regional infrastructure development, the number of implemented investment projects, monitoring compliance with the developed strategic regional programs and concepts, which will ultimately help to effectively and efficiently regulate the detected deviations. The IDRI monitoring mechanism should also provide for the possibility of creating a system for collecting and analysing data based on the assessment of the effectiveness of the infrastructure objects functioning by the territorial community, which will ultimately enable to focus the potential investors not only on analytical data on monitoring of regional authorities but also to take into account real public opinion.

\section{Methodological approaches to regional development monitoring: indicators, criteria, and indexes}

The purpose of monitoring development, as Milashovska O.I. (Milashovs'ka, 2010) noted, is to provide a regional (joint) working group with a monitoring management tool. Indicators are these indexes that monitor and determine the level of social and economic development and the level of progress in fulfilling the specific objectives of the joint strategy and the expected results achievement. Indicators describe the results of the project in operationally measurable quantities. It should be noted that, for many economic processes, it is characteristic that changes from the influence of certain phenomena or factors do not appear immediately but become noticeable only after a certain period of time. In particular, most often the gross regional product acts as a unified indicator of the social and economic development of a region, which is under a significant impact of the investment volume attracted to a region.

While selecting the criteria for the regional capacity monitoring, Hrabánková M., Svatošová L., Boháčková I. (Hrabánková M., Svatošová L., Boháčková I., 2005) noted that for the objective monitoring of regional development, it is not possible to make only a simple statistical analysis that characterize the criteria development, it is advisable to use a target method that would include the dynamics of observed development in certain objects of actual and time communication. This method can be called the process analysis or analysis of selected social and economic and demographic processes, which the authors have adequately tested on the basis of an analysis of structural changes that take place in the regions of the Czech Republic.

While investigating the quantitative and qualitative characteristics of economic structure at the Transcarpathian region, Panko M. (Pan'ko, 2014) has analyzed the indicators that can be used to assess the efficiency of the regional economy structure, justifying the possibility of optimizing the indicators of the economic component of the regional economy structure by developing a complex restructuring program for the production structure.

Adoption of rational administrative decisions in the field of regulation of regional development is 
impossible without monitoring organization of the state of social and economic development of the regions, as Kozhanova E.P. (Kozhanova, 2016) pointed. Monitoring allows timely response to the problems that arose through the adoption of certain managerial decisions aimed at issues resolving. According to the authors' thought, monitoring and assessment of the regions state should provide the application of indicators system that adequately and comprehensively characterizes the development of the regions, its certain territories and sectors, the living standards of the population, the demographic situation, and the attractiveness of the regions for investment attracting.

The system of monitoring indicators and evaluation of the regions' status Matvienko P. suggests to group according to the following blocks: indicators of the efficient use of available resources in the region; indicators of social development; indicators of investment attractiveness of a region; indicators of ecological development (Matviyenko, 2007). It should be noted that the author does not take into account the level of development and efficiency of the infrastructure complex functioning in the region, which greatly affects the overall social and economic development and investment attractiveness of the regions.

The authors of the scientific research (Burtseva T.A., Aleshnikova V.I., Dubovik M.V., Naidenkova K.V., Kovalchuk N.B., Repetskaya N.V., Kuzmina O.G., Surkov A.A., Bershadskaya O.I. \& Smirennikova A.V., 2016) have substantiated the procedures that ensure the implementation of statistical research and monitoring of investment development of Russian regions. They have developed a methodological basis for assessing the investment development of the Russian regions to ensure that their own resources are used more efficiently and aimed to achieve the goals of economic development while identifying the Russian regions, which are "investment points" of growth and regions where investments are inefficiently used to achieve development goals.

Sokolov A.G. and others, (Sokolov A.G.E., Kvyatkovskaya I.Y., \& Zimenkova A.E.E., 2011) emphasize the need to develop the preventive measures to change the investment risk, which is possible if an adequate information environment exists in a region, based on the operation of an information system for monitoring investment risks in the region. A single regional information space creation should be one of the directions of development of investment infrastructure in the region and provide systemic risk management at all levels of the hierarchy, based on the integration of information resources of investment market participants.

The development of a methodological approach that allows obtaining relevant information about a potential recipient of investment on an example of the agro-industrial complex in terms of its territory was investigated by Manzhosova I.B. and others (Manzhosova I.B., Rodina E.V., Dolgopolova A.F., Shepet I.P., \& Ryabov V.N., 2016). The proposed approach is based on the diagnostics of the system of developed indicators of territories differentiation according to the level of their investment development. The authors formed the linguistic characteristics and economic interpretation of the selected classification groups, as well as a separate monitoring stage, which allows identifying a specific economic entity for investing money on the basis of the formation of investment passports of the potential recipients.

The implementation of quantitative methods in regional analysis, according to Gradea C. (Gradea, 2013), can also provide an understanding of both changes in regional economic indicators and interdependencies between economic sectors, including the use of predictions to check the potential future development of a region. Qualitative methods also allow explaining the causes of regional development in a region and improving the ability of analysts to reflect on the results and economic opportunities of the future based on collective experience, wisdom, and judgment of the regional economy subjects.

The problem of effective control over territories in the context of regionalization of processes of social and economic development, as noted by Usenko L. and others (Usenko L.N., Usenko A.M., Uryadova T.N., Bashkatova T.Y.A., \& Beliaeva S.V., 2017), includes the search for optimal forms, methods, and tools for obtaining the necessary information while decisions passing in the field of public administration. Nowadays there are no common technical approaches for monitoring social and economic development as an effective tool for determining the degree of asymmetry of the development of mesoeconomic systems and assessing the impact of the implemented strategic programs. The authors of the research proposed a theoretical model for monitoring the social and economic development of a region, based on a set of interconnected basic components: functions, monitoring objects, and requirements for its realization and main goals.

According to Bobrysheva A.N. and others (Bobryshev A.N., Kazakov M.Yu., 2011), the main tasks facing the monitoring of the effectiveness of regional social and economic systems functioning, are: search for ways and reserves to increase the rational use of all kinds of resources; identification of optimality of managerial decisions under the influence of crisis phenomena in certain industries and in regions of the economy as a whole; search for the relevant information for the purpose of implementing program-targeted activities at the level of a region or a separate territory; detection of the marginal utility of the interaction between individual business entities and other elements of the regional social and economic system; diagnostics of 
the results of infrastructure provision of specialization areas; analysis of the degree of social and economic effects of the development of individual territories and the region as a whole achievement; escalation of investment attractiveness of individual territories by increasing image and reputation characteristics of a region; production of relevant data to achieve maximum competitive advantage, oriented to the output of individual enterprises, within the framework of the identified growth points, to new geographic segments.

The analysis of scientific developments regarding the development and implementation of the mechanism for the monitoring and evaluation of regions development indicates the dominant direction of research in the field of social and economic development and the practical absence of mechanisms for taking into account the level of infrastructure development in the regions or the effectiveness of their functioning, thus, the actuality of this research is to substantiate the necessity to formulate a process monitoring in the direction of investment support of infrastructure development of Ukrainian regions.

\section{Monitoring results of the social and economic development of Ukrainian regions during 2015-2016}

The monitoring results of the social and economic development of the regions for 2016 in the direction of "Investment development" (Ministerstvo rehional'noho rozvytku, budivnytstva ta zhytlovo-komunal'noho hospodarstva Ukrayiny) (in the list of evaluation indicators given in Annex 2 to the Resolution of the Cabinet of Ministers of Ukraine dated on October 21, 2015 No. 856 "On Approval of the Procedure and
Methodology for Monitoring and Evaluation of the Effectiveness of the Implementation of State Regional Policy"), Fig. 1, are based in particular on the following indicators of the direction: 1) capital investment index, percentages to the previous year; 2) the volume of capital investments (except of investments from the state budget) per head of population as an incremental result of the beginning of the year, $\mathrm{UAH} ; 3$ ) the rate of growth (decrease) in the volume of direct foreign investment (share capital), percentage to the amount at the beginning of the year; 4) the volume of direct foreign investments per head as an incremental result of the beginning of the investment, USD.

At the same time, the trends of the capital investment index during 2016 to the previous year by the regions indicate a positive dynamics in the Odesa region, 63.4\%; Mykolaiv region, 47.6\%; Kirovohrad region, $47.0 \%$. Nevertheless, the negative dynamics is observed in Ivano-Frankivsk region, $-34.7 \%$; Chernivtsi region, $-14.1 \%$; Rivne region, $-8.8 \%$; Transcarpathian region, $-6.1 \%$. According to the volume of capital investments (except for investments from the state budget) per head, as an incremental result of the beginning of the year, the city of Kyiv is a leader -32922,5 UAH and the absolute negative dynamics in Luhansk region $1257,8 \mathrm{UAH}$. The rate of growth (decrease) in the volume of direct foreign investments (share capital) is positively monitored in Chernihiv region, $161.5 \%$ up to the beginning of the year, and absolutely negative in Luhansk region, $-14.6 \%$. The volume of direct foreign investments (share capital) per head is growing at the beginning of the investment in positive dynamics in the city of Kyiv - 7468,8 USD, and absolutely negative in Ternopil region. - 45.8 USD.

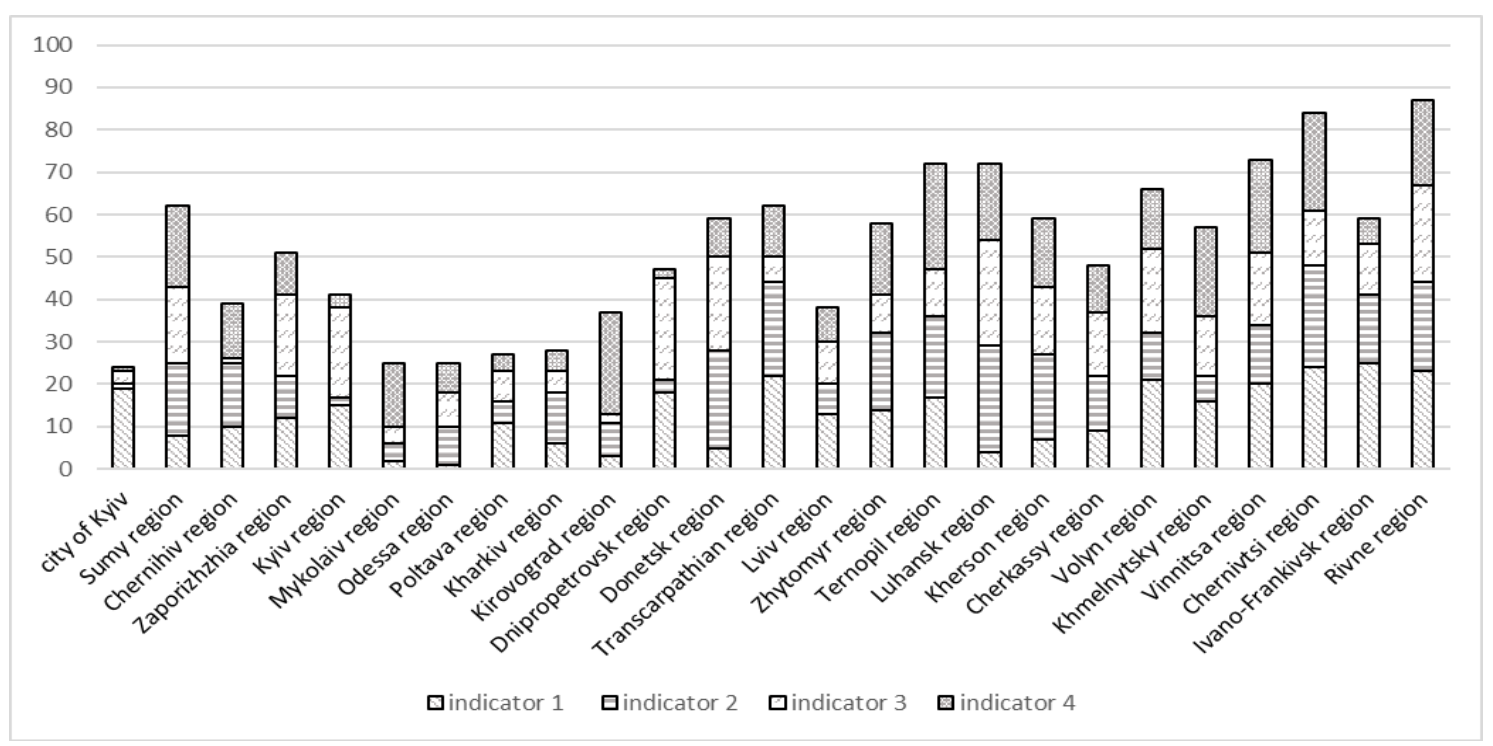

Fig. 1. The monitoring results in the direction of "Investment development" of the regions of Ukraine for 2016

Source: formed on the basis of data (Ministerstvo rehional'noho rozvytku, budivnytstva ta zhytlovo-komunal'noho hospodarstva Ukrayiny) 
Monitoring of social and economic development of the regions for 2016 in the direction of "Infrastructure development" (Ministerstvo rehional'noho rozvytku, budivnytstva ta zhytlovo-komunal'noho hospodarstva Ukrayiny) (in the list of evaluation indicators given in Annex 2 to the Resolution of the Cabinet of Ministers of Ukraine dated on October 21, 2015 No. 856 "On Approval of the Procedure and Methodology for Monitoring and Evaluation of the Effectiveness of the Implementation of State Regional Policy") is presented in Fig. 2 according to the following indicators of the direction: 1) the density of public highways with a solid coverage of state and local importance in a region, kilometres per thousand square kilometres; 2) the volume of cargo turnover of road and rail transport, thousand tons of kilometres per 1000 population; 3 ) the proportion of urban households having access to the Internet at home, as a percentage of the total number of such households; 4) the proportion of rural households with Internet access at home, as a percentage of the total number of such households; 5) the rate of growth (decrease) in the volume of residential housing accepted, the percentage of the corresponding period of the previous year; 6) the total area of the housing stock per head, sq. meters.

It should be noted that in the infrastructure development of the regions, the transport connection is a significant criterion, in particular, by the density of public highways with a solid coverage of state and local importance, Lviv region occupies leading positions $376.2 \mathrm{cl}$. per thousand sq. cl.; negative trends are observed in the Kherson region $-174.3 \mathrm{cl}$. per thousand sq. cl.; Mykolaiv region - $194.5174 .3 \mathrm{cl}$. per thousand sq. cl.; Chernihiv region - $226.7 \mathrm{cl}$. per thousand sq. cl. At the same time, the volume of cargo turnover of road and rail transport - the positive trends are in Kirovohrad region - 21329,3 thousand of tons-cl. per 1,000 people and totally negative in Luhansk region 993,9 thousand tons-cl. per 1000 population; Kherson region - 1081,9 thousand tons-cl. per 1000 population. The information value, in particular for potential investors, the indicator analysis of the share of urban households and rural households with internet access at home are the controversial issues in the report of the Ministry of Regional Development, Construction, Housing and Utilities of Ukraine "Monitoring of the Social and Economic Development of the Regions for 2016 " by the direction of "Infrastructure development" (Ministerstvo rehional'noho rozvytku, budivnytstva ta zhytlovo-komunal'noho hospodarstva Ukrayiny). The monitoring results of the regions both in the directions of "Investment development" and "Infrastructure development" indicate a significant spatial asymmetry of IDRI, which negatively affects the implementation of both national development strategies and regional programs and concepts.

Thus, the generalized comparative monitoring of the regions of Ukraine by the directions of "Investment development" and "Infrastructure development" (Figure 3) shows the following: the impairment of the financial position of producers and the lending reduction; insufficient institutional provision of investment policy in the regions; imperfection of tools for disclosing the internal potential of the regions through regional strategies; the decline of the volumes of investment attractiveness due to the impairment of the social and economic situation in the country and the decline in the investment attractiveness of the regions of

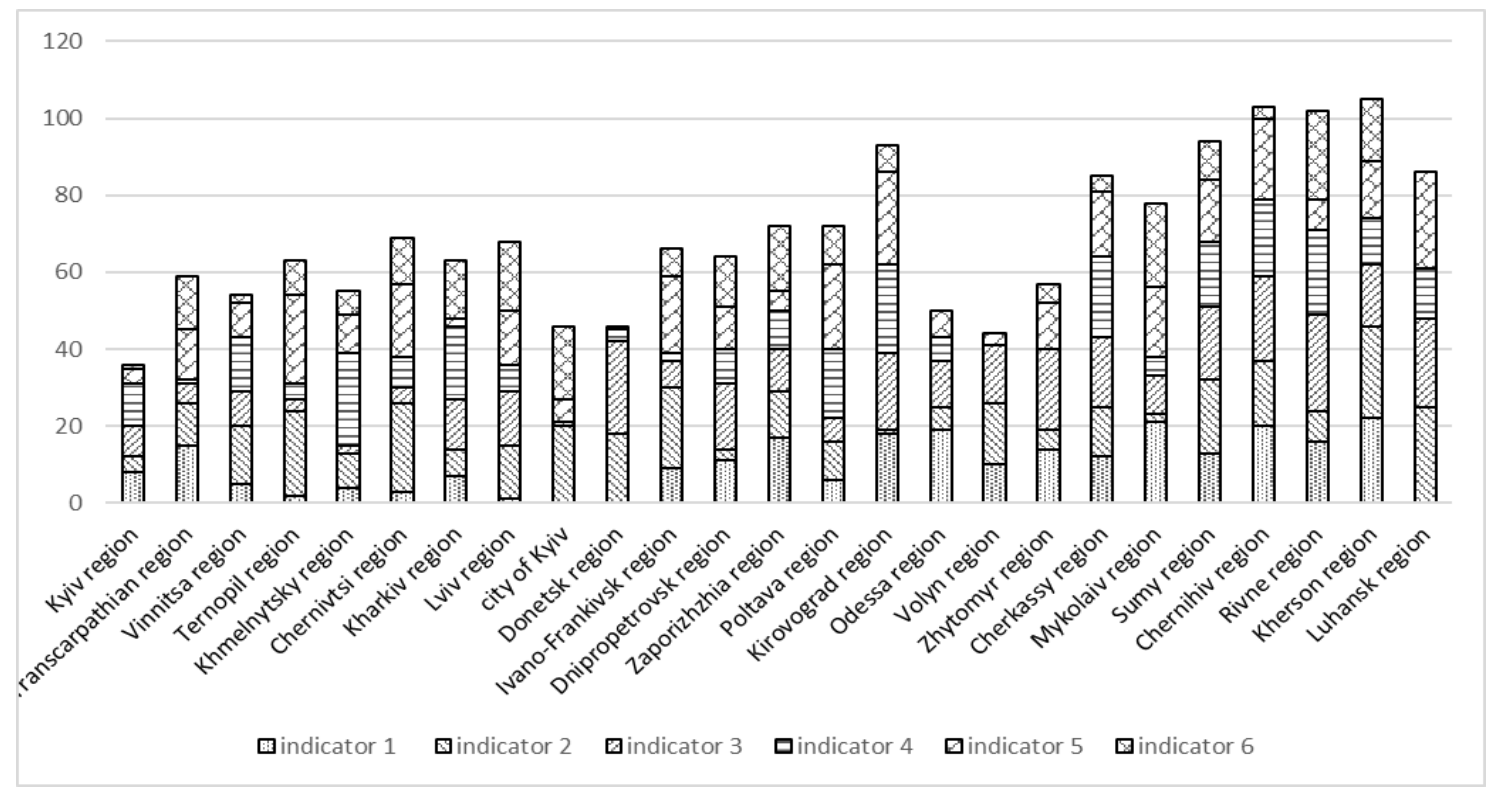

Fig. 2. The monitoring results in the direction of "Infrastructure development" of the regions of Ukraine for 2016

Source: formed on the basis of data (Ministerstvo rehional'noho rozvytku, budivnytstva ta zhytlovo-komunal'noho hospodarstva Ukrayiny) 


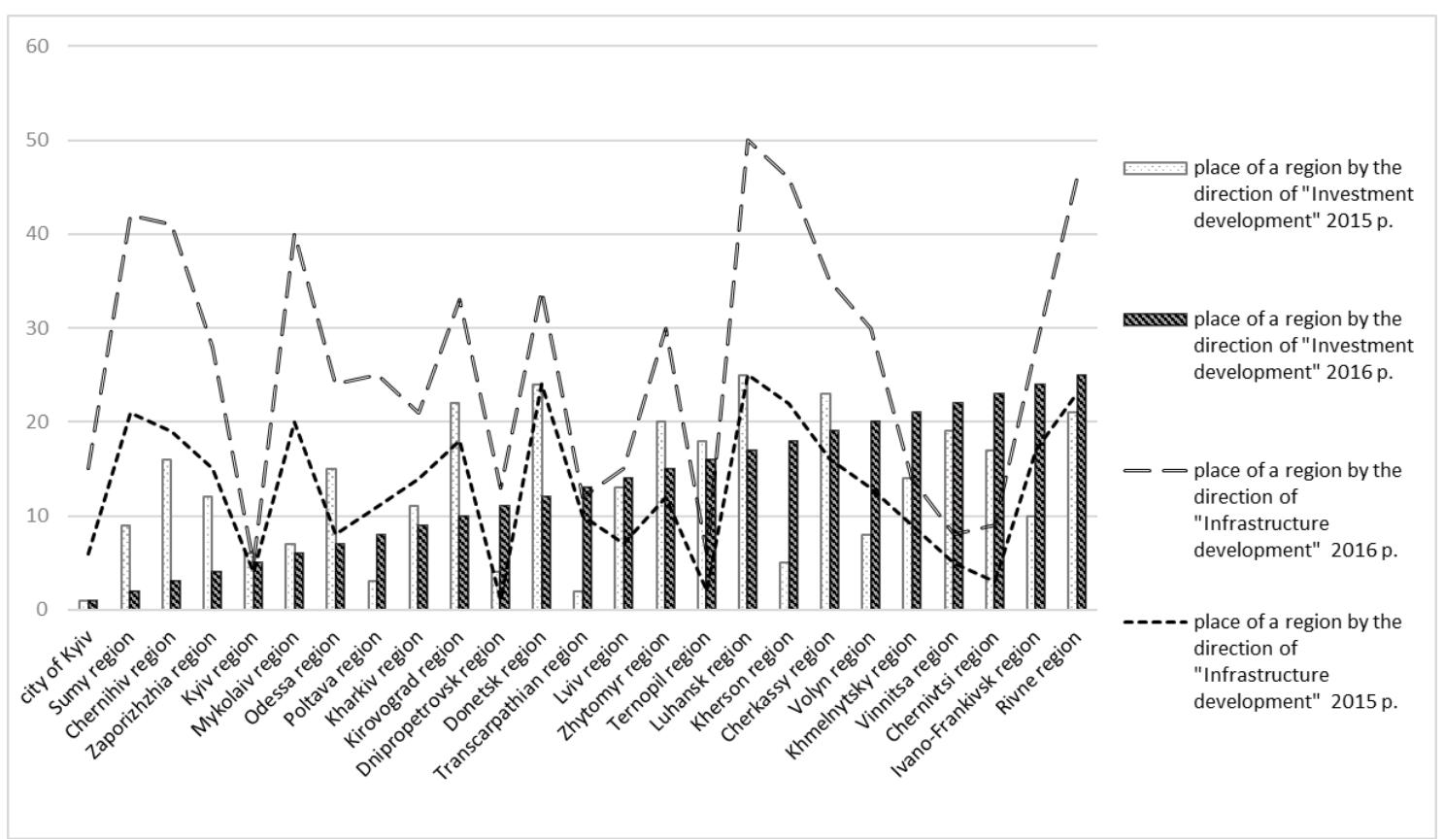

Fig. 3. Place of the regions by the direction of the IDRI for 2015-2016

Source: formed on the basis of data (Ministerstvo rehional'noho rozvytku, budivnytstva ta zhytlovo-komunal'noho hospodarstva Ukrayiny)

Eastern Ukraine through the conduct of hostilities on their territory; inefficiency of separate instruments of capital projects financing; low efficiency of investment distribution, and low return on investment.

\section{General principles of monitoring mechanism of investment development of the regions' infrastructure (IDRI)}

I. Complex and system observation and data collection of IDRI. For the analysis of the development level of the infrastructure complex of the regions and investment activity, the objective indicators are required, the source of which should be a monitoring system, built on the modern systems of accounting, collection, storage, and processing of data. During IDRI monitoring, there is a need to obtain information, which is representative of various infrastructure objects and potential investors. The developed set of indicators should reflect the change in the level of investment potential as a result of the implementation of measures and implementation of investment projects for the development of regional infrastructure.

II. Estimation of the efficiency level of the regional infrastructure functioning. It should be noted that there are no complex indicators for assessing the development and functioning of the infrastructure complex of the regions that would distinguish one region from another, both by external and internal parameters. Therefore, there is a need to find an approach and develop methods for assessing the level of effectiveness of the development and operation of the infrastructure complex of the regions, which would enable the complex consideration of all aspects of the research of the IDRI and help to identify the causes of inefficient infrastructure development. An efficiency analysis of the development and operation of the infrastructure complex of the regions is possible only under condition that benchmarking procedures will be used - concept of benchmarking. Benchmarking allows you to find strategies and practices that have helped some entity to achieve results in improving performance. Benchmarking equally involves evaluation and comparison. The system of benchmarking should provide: a systematic comparative analysis of the infrastructure objects indicators, trends in their changes, and determination of the efficiency level of their functioning; identification of the causes of inefficient functioning of infrastructure objects and ways of their elimination; analysis of the dynamics of the level of IDRI as a reflection of the effectiveness of management actions to increase the investment potential of the regions. Information, gathered in the process of benchmarking, should be the basis for further enhancing the level of IDRI and used for planning an effective IDRI, as well as controlling the functioning of infrastructure objects and the effectiveness of the decisions taken. Implementation of benchmarking allows reducing the cost of improvement processes because the best experience of managing of other territories is studied and evaluated in order to use the acquired knowledge in the activities of the authorities.

At the same time, the main advantages of benchmarking using to improve the infrastructure 
provision of regional development are: successful use in various spheres of activity as one of the most common management methods; use of benchmarking can save resources for the infrastructure development by finding ready-made solutions or their "semi-finished products"; the effectiveness of benchmarking depends on the justification of the choice of objects required for a comparison, and a detailed analysis of the individual components of the process of infrastructure development management; increasing the effectiveness of benchmarking applying is possible if the information base is expanded (Butyrs'ka I. V., 2005).

Thus, the systemic implementation of the IDRI monitoring mechanism will facilitate to the adoption of effective management decisions aimed at increasing of the investment attractiveness of the regions and, accordingly, the development of the infrastructure of the regions of Ukraine.

\section{Conclusions}

Consequently, the IDRI monitoring system should provide a clear definition of the form of its implementation with the definition of resulting indicators monitoring, monitoring of the programs and projects for the regions' infrastructure development. Based on the results of IDRI monitoring, it is necessary to evaluate and review the results of management of investment potential and regions policy on the basis of its infrastructure development. At the same time, the main principles of the formation of the IDRI monitoring mechanism are: orientation of the monitoring system to the implementation of the regional development strategy, which provides for the primary control and management of the main (strategic) deviations, that is, the accounting of a rate for a limited number of controlled indicative parameters; multifunctionality of monitoring - supervision and control is carried out in many indicators, taking into account their interconnection and interdependence, that is, the formation of a limited range of interrelated indicators should be provided, so-called evaluation directions; the orientation of monitoring for the quantitative assessment of parameters, which determines the uniqueness of the conclusions and management actions that are formed on its basis; careful selection of controlled parameters to prevent the redundant actions that lead to increased analytical and managerial costs. Undoubtedly, the systemic and complex results of IDRI monitoring are an important source of information for the potential investors but, for the improvement of the investment climate of the Ukrainian regions, a complex program for ensuring an effective investment policy within the declared priorities of the social and economic regions' development is not enough, but it is necessary to have also regional plans to increase the investment attractiveness of the regions taking into account the peculiarities of current ratings of investment attractiveness, the implementation of the practice of all agreements concluding between all interested parties of the IDRI, namely, investors, regional authorities and the territorial community regarding mutual obligations.

\section{References:}

Bobryshev, A. N., Kazakov, M. Yu. (2011). Conceptual bases for monitoring of the social and economic development of a region. Kant, (2).

Butyrs'ka, I. V. (2005). Organizational and economic principles of infrastructure provision of regional development: avtoref. dys. na zdobuttya nauk. stupenya kand. ekon. nauk : spets. "Rozmishchennya produktyvnykh syl i rehional'na ekonomika", L'viv, 20.

Burtseva, T.A., Aleshnikova, V.I., Dubovik, M.V., Naidenkova, K.V., Kovalchuk, N.B., Repetskaya, N.V., Kuzmina, O.G., Surkov, A.A., Bershadskaya, O.I. \& Smirennikova, A.V. (2016). Statistical Research of Investment Development of Russian Regions. International Journal of Environmental and Science Education, 11(15): 8182-8192.

Gradea, C. (2013). Analysis and planning of regional development-contextual variables to develop a model for monitoring financial indicators at regional level. Annals-Economy Series, 6: 180-184.

Hrabánková, M., Svatošová, L., Boháčková, I. (2005). Monitoring of regional development dynamics with use of process analysis. Agricultural Economics, 3: 112-116.

Kozhanova, Ye. P. (2016). Methodological approaches to the assessment of the social and economic development of the regions of Ukraine. Materialy Vseukr-yi nauk.-prakt-yi konf-yi «Publichne upravlinnya: problemy ta perspektyvy», Kh., TOV «Konstanta», 405-409.

Lohutova, T. H. (2006). Organizational and economic mechanism of state management of innovative development in a region. Donets. hos. un-t upr., Pryazov. hos. tekhn. un-t. - Maryupol' : Pryazov. hos. tekhn. un-t, 224.

Manylich, M. I. (2005). Strategy of recreation of a regional economic complex: to the modern paradigm. Zbirnyk naukovykh prats' Chernivets'koho finansovo-yurydychnoho instytutu. Ekonomichni nauky. Chernivtsi: Bukrek, 1: 52-64.

Matviyenko, P. (2007). Summary evaluation of regional development. Ekonomika Ukrayiny, 5: 26-35.

Manzhosova, I. B., Rodina, E. V., Dolgopolova, A. F., Shepet, I. P., \& Ryabov, V. N. (2016). Monitoring parameters related to investment activity in the agrarian sector of regions economies. The Journal of Internet Banking and Commerce, 21(3). 
Milashovs'ka, O. I. (2010). Monitoring of the joint strategy of social and economic development of the regions of the Carpathian region. Naukovyy visnyk Instytutu mizhnarodnykh vidnosyn Natsional'noho aviatsiynoho universytetu, 2: 119-125.

Ministerstvo rehional'noho rozvytku, budivnytstva ta zhytlovo-komunal'noho hospodarstva Ukrayiny. [Elektronnyy resurs]. Rezhim dostupu: http://www.minregion.gov.ua/napryamki-diyalnosti/regional-dev/derzhavna-rehionalna-polityka/monitorynh/monitorynh-monitorynh/osnovni-tendentsiyi-sotsialno-ekonomichnogo-rozvitkuregioniv/osnovni-pokazniki-sotsialno-ekonomichnogo-rozvitku-regioniv-7/

Pan'ko, M. (2014). Monitoring of economic indicators of the structure of the region's economy and ways for their improvement. Halyts'kyy ekonomichnyy visnyk, Ternopil' : TNTU, 47, 4: 40-48.

Sokolov, A. G. E., Kvyatkovskaya, I. Y., \& Zimenkova, A. E. E. (2011). Information system of monitoring of regional investments risks. Vestnik of Astrakhan State Technical University. Series: Management, Computer Sciences and Informatics, (1): 181-186.

Usenko, L. N., Usenko, A. M., Uryadova, T. N., Bashkatova, T. Y. A., \& Beliaeva, S. V. (2017). Monitoring methodology for socio-economic development of a region (through the example of the South of Russia regions). Revista ESPACIOS, 38(23).

\section{Галина ЛЕЩУК}

\section{МЕХАНИЗМ МОНИТОРИНГА ИНВЕСТИЦИОННОГО РАЗВИТИЯ ИНФРАСТРУКТУРЫ РЕГИОНОВ}

Аннотация. Предметом исследования является теоретико-методологические основы механизма мониторинга инвестиционного развития инфраструктуры регионов. Цели исследования заключаются в обобщении теоретико-методологических основ механизма мониторинга инвестиционного развития инфраструктуры регионов, а также анализе современных тенденций инвестиционного развития инфраструктуры регионов Украины с выделением положительных и отрицательных тенденций. Методология. В статье рассмотрены теоретико-методологические подходы к определению концептуальных основ механизма мониторинга инвестиционного развития инфраструктуры регионов с помощью общенаучных методов анализа: систематизации и обобщения, индукции, дедукции. Результаты. Предложено мониторинг инвестиционного развития инфраструктуры регионов трактовать как системное и комплексное измерения индикаторов инфраструктурного развития регионов, количества реализованных инвестиционных проектов, наблюдения соответствия соблюдения разработанным стратегических региональных программ и концепций, в итоге будет способствовать эффективному и оперативному регулированию выявленных отклонений и принятия соответствующих решений. Механизм мониторинга инвестиционного развития инфраструктуры регионов должен также предусматривать возможность создания системы сбора и анализа данных по оценке инфраструктурных объектов территориальной общиной, позволит для потенциальных инвесторов ориентироваться не только на аналитические данные мониторинга органов управления региона, но и учитывать общественный интерес в том или ином регионе. Предложены общие принципы механизма мониторинга инвестиционного развития инфраструктуры регионов интерпретировать по направлениям: комплексного и системного наблюдения и сбора данных по развитию инфраструктуры регионов, при этом сложившаяся совокупность показателей должна отражать изменение уровня инвестиционного потенциала в результате внедрения мероприятий и реализуемость инвестиционных проектов развития инфраструктуры регионов; оценивания уровня эффективности функционирования инфраструктуры регионов при условии использования процедур сравнительного анализа - концепции бенчмаркинга, что соответствующим образом позволит уменьшить затраты на процессы совершенствования, поскольку изучается и оценивается лучший опыт управления другими территориями с целью использования полученных знаний в деятельности органов власти. Выводы. Исследованы теоретико-методологические основы механизма мониторинга инвестиционного развития инфраструктуры регионов позволили обосновать необходимость имплементации комплексного и системного наблюдения функционирования инфраструктурного комплекса и инвестиционного потенциала регионов. Проанализированы тенденции инвестиционного развития инфраструктуры регионов Украины позволили установить значительные пространственные асимметрии, негативно влияет на реализуемость как общегосударственных стратегий развития, так и региональных программ и концепций. От так основные направления механизма мониторинга инвестиционного развития инфраструктуры регионов в композиции должны основываться на аналитическом наблюдении не только органов регионального управления, но и потенциальных инвесторов и территориальной общины. Практическое значение. На основе официальных 
статистических данных мониторинга инвестиционного обеспечения и уровня развития инфраструктурного комплекса регионов Украины в статье исследовано тенденции инвестиционного развития инфраструктуры регионов, позволяет утверждать о значительных территориальных диспропорциях как уровня инвестиционного обеспечения, так и эффективности функционирования инфраструктурного комплекса регионов, а от так предопределяет необходимость разработки комплексных программ регионального развития и надлежащего контроля их реализации по инвестиционного обеспечения инфраструктуры регионов. Системная имплементация механизма мониторинга инвестиционного развития инфраструктуры регионов будет способствовать принятию результативных управленческих решений для всех участников данного процесса, а именно территориальной общины, инвесторов, региональных органов власти, в соответствии повышать инвестиционную привлекательность регионов и развитие инфраструктуры регионов Украины. 